\title{
Penerapan Manajemen Berbasis Database Dengan MS Access Untuk Meningkatkan Keunggulan Bersaing Pada Usaha Mikro
}

\author{
Ellysa Nursanti*), Fourry Handoko, Prima Vitasari \\ Program Studi Teknik Industri, Program Pascasarjana, Institut Teknologi Nasional Malang \\ Jl. Bendungan Sigura-gura 2 Malang, 65145 \\ *)Email : ellysa.nursanti@lecturer.itn.ac.id
}

\begin{abstract}
Abstrak
Manajemen tata kelola pada unit usaha mikro, UMKM, seringkali menjadi hambatan bagi unit usaha tersebut untuk bertahan, bahkan mampu berkembang maju. Umumnya industri kreatif rumah tangga ini memiliki kemampuan tata kelola manajerial yang kurang memadai. Hal ini juga terlihat pada UMKM Bhakti Collection yang bergerak di bidang produksi kerudung border dan sulam tangan. Usaha ini memiliki banyak permintaan dan penjualan, tersebar di kota-kota besar Indonesia, namun ternyata manajemen tata kelolanya masih dilakukan dengan pencatatan manual, sehingga sering terjadi kehilangan barang dan sulit melakukan pelacakan pengontrolan. Kegiatan pengabdian pada masyarakat ini membantu UMKM dalam memperbaiki manajemen pengelolaan produk dan transaksinya dengan pendekatan manajemen berbasis database menggunakan aplikasi MS Access. Perekaman database dilakukan dengan mengelompokkan jenis bahan, model, motif, aplikasi, pekerja, waktu produksi, juga dengan menambahkan informasi harga, lokasi penyimpanan, jumlah stok, rekaman transaksi dan identitas pembeli/pemesan. Kegiatan ini memberikan banyak kontribusi langsung terhadap UMKM. Manajemen inventori baik bahan baku, penunjang, maupun produk jadi dapat dikelola dengan baik. Transaksi pemjualan dan pemesanan produk terekam dengan baik. Katalog produk juga semakin mudah di monitor dan di update. Perbaikan manajemen tata kelola usaha ini membawa dampak signifikan positif terhadap UMKM, sehingga diharapkan UMKM dapat meningkatkan keunggulan bersaingnya di masa mendatang.
\end{abstract}

Kata Kunci: Database, Inventori, Keunggulan Bersaing, Transaksi, Usaha Mikro.

\section{Pendahuluan}

Manajemen tata kelola pada unit usaha mikro, UMKM, seringkali menjadi hambatan bagi unit usaha tersebut untuk bertahan, bahkan mampu berkembang maju. Umumnya industri kreatif rumah tangga ini memiliki kemampuan tata kelola manajerial yang kurang memadai. Hal ini juga terlihat pada UMKM Bhakti Collection yang bergerak di bidang produksi kerudung border dan sulam tangan. Usaha ini memiliki banyak permintaan dan penjualan, tersebar di kota-kota besar Indonesia, namun ternyata manajemen tata kelolanya masih dilakukan dengan pencatatan manual, sehingga sering terjadi kehilangan barang dan sulit melakukan pelacakan pengontrolan Seiring dengan semakin ketatnya persaingan produk, Bhakti Collection harus dapat meningkatkan kualitas produk dan melakukan evaluasi efisiensi sehingga produk memiliki kualitas dan harga yang mampu bersaing di pasar [1]. Sementara di lapangan, hasil sulaman tangan masing-masing pengrajin relatif berbeda, sehingga kualitas sulaman kerudung yang dihasilkan menjadi bervariasi. Terkadang kombinasi warna benang yang disiapkan sebelumnya juga tertukar sehingga kualitas sulaman kerudung yang dihasilkan menjadi kurang. Pada kasus ini risiko terhadap variasi kualitas menjadi beban yang ditanggung oleh UMKM Bhakti Collection. Pihak UMKM kesulitan untuk melakukan kontrol kualitas dan pelacakan identitas 
produk, siapa saja pekerja yang terlibat dalam pembuatan setiap unit produk, mulai dari tukang potong, tukang jahit, tukanggambar, penyulam, tukang pasang payet, tukang pasang permata dan petugas pencuci pengemas. Kurangnya kontrol kualitas ini berdampak pada pengembalian produk oleh pelanggan, yang harus di rework ataupun dijual rugi, bahkan tidak dapat dijual kembali. Jika hal ini tidak segera diatasi, usaha ini terancam mengalami penurunan omset penjualan karena ketidakpuasan konsumen. Persoalan lain yang timbul adalah kurangnya pengelolaan sistem persediaan produk jadi.

Transaksi keluar masuknya barang belum dilakukan dengan baik dan sistematis, sehingga sering terjadi kehilangan produk. Banyaknya varian produk juga membuat pemilik kesulitan untuk melakukan kontrol status persediaan produk akhir. Pada makalah ini, persoalan kontrol kualitas dan sistem persediaan tersebut diatasi dengan memanfaatkan sistem Database [2][3]. Sistem Database yang digunakan, diharapkan dapat merekam dan melakukan pelacakan identitas setiap pekerja yang terlibat pada setiap unit produk yang dihasilkan, sehingga kontrol kualitas dan kinerja penyulam dapat dilakukan dengan baik. Label identitas histori produk melalui sistem database juga sekaligus dapat digunakan untuk mengatasi masalah persediaan produk akhir. Pengelolaan transaksi keluar masuk produk diharapkan dapat lebih mudah dikontrol.

\section{Deskripsi Sistem}

Kegiatan pengabdian pada masyarakat ini membantu UMKM dalam memperbaiki manajemen pengelolaan produk dan transaksinya dengan pendekatan manajemen berbasis database menggunakan aplikasi MS Access. Perekaman database dilakukan dengan mengelompokkan jenis bahan, model, motif, aplikasi, pekerja, waktu produksi, juga dengan menambahkan informasi harga, lokasi penyimpanan, jumlah stok, rekaman transaksi dan identitas pembeli/pemesan.

\section{Membangun Database}

Dimulai dengan studi lapangan untuk mendapatkan mapping persoalan. Selanjutnya adalah perumusan masalah dan pengelompokan produk berdasarkan kriteria model, bahan, jenis, motif dan pengrajin. Tahap berikutnya adalah pengadaan perangkat lunak (software) pendukung sistem database untuk pembuatan database produk. Selanjutnya adalah melakukan peng kode an database katalog produk, hasil klasifikasi, penyiapkan, sertamemasang label [4]. Berikutnya adalah pembuatan program yang berisi data produk, supplier, pembeli, transaksi penjualan dan kas masuk keluar serta inventory, melakukan input data-data yang dibutuhkan, serta singkronisasi data. Teknologi yang digunakan adalah sistem database dengan aplikasi MS ACCESS. Sistem database merekam data identitas produk dan sejarah produksinya dari bahan dasar kain kerudung sampai menjadi kerudung sulam siap jual. Sistem ini merekam data siapa saja pekerja yang terlibat di dalam pembuatannya, mulai dari tukang potong, tukang jahit, tukang gambar, penyulam, tukang pasang payet, tukang pasang aplikasi, karyawan bagian pencucian dan pengemasan. Sistem ini akan memudahkan kontrol kualitas [2][4][5]. Pengkodean database terdiri dari 10 digit dengan urutan 1 sampai dengan 10 secara berturut-turut sebagai berikut:1. Model, 2. Bahan, 3. Jenis, 4. Motif, 5. Tukang Potong, 6. Tukang Gambar, 7. Kelompok Penyulam, 8. Nomor Identitas Penyulam, 9. Tukang Payet, 10. Tukang Permata. Sistem ini juga akan merekam setiap transaksi keluar masuknya produk, sehingga memudahkan kontrol persediaan. Setelah produk dikelompokkan berdasarkan ragam tersebut, maka selanjutnya data yang didapat dimasukkan ke dalam tabel untuk dibuat dalam database guna memudahkan dalam pengkodean/klasifikasi jenis produk. Sehingga memudahkan dalam melakukan transaksi penjualan dan kontrol persediaan serta kualitas [6]. Adapun hasil pengkodean dan penginputan berbagai jenis produk dalam database,nampak dalam gambar 1. 


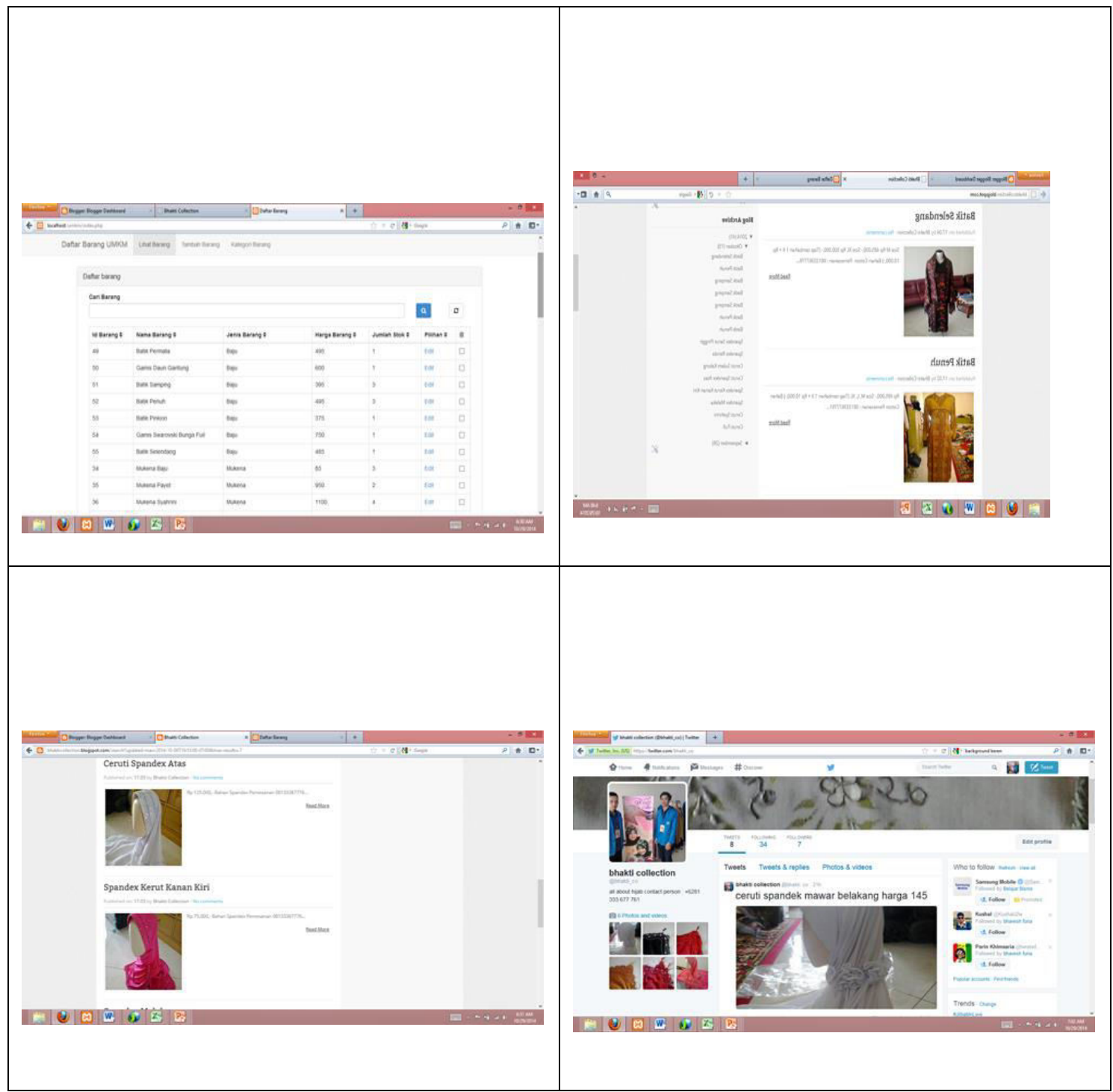

Gambar 1. Gambar Hasil Database Produk

\section{Hasil dan Manfaat}

Sistem database yang dihasilkan dapat digunakan untuk mencatat data historis setiap tahapan kegiatan proses produksi baik nama pekerja maupun waktu pengerjaannya sehingga memudahkan untuk kontrol kualitas dan pelacakan data pekerja yang terlibat. Sistem database juga memudahkan kontrol transaksi, sehingga dapat dievaluasi produk-produk mana yang banyak diminati dan mana yang kurang, sehingga keputusan manajerial terhadap produk dapat segera dilakukan. memudahkan pengecekan status persediaan produk akhir. Sistem database juga bermanfaat untuk memudahkan pemilik UMKM melakukan penilaian terhadap kinerja setiap pegawainya sehingga pemberian bonus dan jumlah pekerjaan dapat diberikan secara adil sesuai dengan kinerjanya masing-masing.

\section{Diskusi}

Kegiatan ini memberikan banyak kontribusi langsung terhadap UMKM. Manajemen inventori baik bahan baku, penunjang, maupun produk jadi dapat dikelola dengan baik. Transaksi pemjualan dan pemesanan produk terekam dengan baik. Katalog produk juga semakin mudah di monitor dan di update. Perbaikan manajemen tata kelola usaha ini membawa dampak signifikan positif terhadap UMKM, sehingga diharapkan UMKM dapat meningkatkan keunggulan bersaingnya di masa mendatang. 


\section{Kesimpulan}

Dengan pemanfaatan manajemen database, persoalan inventory dan transaksi dapat diatasi, komplain pelanggan dapat dihindari, tidak ada lagi kehilangan produk, profit meningkat dan kepuasan pelanggan dapat diwujudkan. Kondisi ini tentunya secara tidak langsung akan meningkatkan keunggulan bersaing bagi UMKM di masa yang akan datang. Database juga dapat dikembangkan pada langkah berikutnya sebagai materi pemasaran produk lewat media online.

\section{Daftar Referensi}

[1] Zieger, Anne (2003). "Retailer chargebacks: is there an upside? Retailer compliance initiatives can lead to efficiency", Frontline Solutions.

[2] Varchaver, Nicholas (2004). "Scanning the Globe". Fortune.

[3] Anderson, Kelly (2011). "NFB, ARTE France launch 'Bar Code'". Reelscreen.

[4] Harmon and Adams (1989). Reading Between The Lines, p.13. Helmers Publishing, Inc, Peterborough, New Hampshire, USA.

[5] Nelson, Benjamin (1997). From Punched Cards To Bar Codes. 